\title{
Nutritional Aspects of Pyridoxal as a Coenzyme
}

\author{
By H. M. Sinclair, Laboratory of Human Nutrition, \\ University of Oxford
}

\section{Introduction}

In the quarter of a century that has elapsed since Goldberger \& Lillie (1926) first described a ' pellagra-like' dermatitis in rats fed mainly maize extracted with alcohol, two main phases of progress may be distinguished. First, the macroscopic changes in the rat and other lower animals were studied mainly by György, by Chick and by Lepkovsky with their colleagues; and the factor preventing these lesions was differentiated from the pellagra-preventing factor and riboflavin, was named vitamin $B_{6}$ (György, r934) or pyridoxin (György \& Eckhardt, I939), was crystallized (Lepkovsky, I938a, $b$; Keresztesy \& Stevens, 1938; György, 1938; Kuhn \& Wendt, I938a, $b$; Itiba \& Miti, 1938), and was synthesized (Harris \& Folkers, 1939a, $b$; Kuhn, Westphal, Wendt \& Westphal, 1939; Morii \& Makino, 1939). Secondly, the coenzyme function of vitamin $\mathrm{B}_{6}$ was elucidated mainly through the use of microorganisms by Snell (cf. Snell, I952), Gunsalus (cf. Gunsalus, r950) Gale (cf. Gale, 1946) and others.

It will be convenient first to describe the macroscopic and microscopic effects of deficiency of vitamin $B_{6}$ as seen in lower animals and in man, then to mention briefly the proved or suggested coenzyme functions of the vitamin, and finally to attempt to correlate the two. The term vitamin $B_{6}$ will be retained to cover pyridoxin, pyridoxal, pyridoxamine and other derivatives (such as the lactones of pyridoxic acids-pyracins) that have similar biological activity.

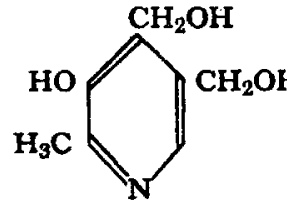

Pyridoxin

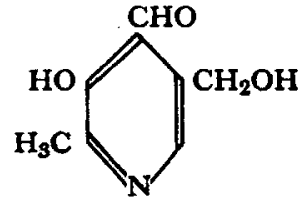

Pyridoxal

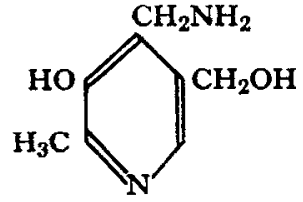

Pyridoxamine<smiles>CC1CCCCC1COC(=O)O</smiles>

$\beta$-Pyracin

\section{Biological effects of deficiency of vitamin $B_{6}$}

Weanling rats on a diet free of vitamin $B_{6}$ fail to grow, then lose weight and die; adult rats similarly lose weight and die. The rate with which weight is lost and the period of survival depend upon the source of carbohydrate in the diet (unless an antibiotic is given to diminish the bacterial flora) and upon the level of protein in the diet, since animals fed a high-protein diet die earlier than those on low protein. The main changes in all animals are found in the skin, the haematopoietic tissue, and the nervous system. 
Skin

Animals. In the rat and mouse, skin changes are prominent in deficiency of vitamin $B_{6}$. They were described in detail in weanling rats by Sullivan \& Nicholls (1940) and by Antopol \& Unna (1942). More recently we have been studying the lesions and noted that involvement of the mucocutaneous junctions occurred early (Ramalingaswami \& Sinclair, I950a, I953). In adult rats the clinical signs begin to appear when weight begins to decrease (after about 10-14 weeks on a diet containing $20 \%$ by weight of purified casein), and the rats die after a further 10-14 weeks. The earliest changes consist of erythema, oedema, loss of hair and scaliness of the dorsal aspects of the digits and paws, found earliest in the hind ones. At the same time the angles of the mouth, the lips and nose are involved; later the anogenital region and the eyelids are involved. We have never seen corneal vascularization in deficiency of vitamin $B_{6}$.

Microscopically, the skin of the anterior abdominal wall shows loss of subcutaneous fat, atrophy of transitional layers of the epidermis with surface hyperkeratosis but no parakeratosis; late in deficiency there is atrophy of the sebaceous glands and hair follicles. The lesion is much more marked in the dorsa of the paws, where there is severe hyperkeratosis and acanthosis, and some parakeratosis; there is oedema and vascular dilatation in the corium with some diffuse mononuclear cell infiltration, but the sebaceous glands are usually normal. The lesions in the lips, mouth and nose are similar to those in the paws. The cornea and conjunctiva are normal.

Similar changes occur in the mouse in deficiency of vitamin $B_{6}$. In the Syrian hamster, dermatitis occurs around the mouth (Routh \& Houchin, 1942), and the monkey develops a seborrhoeic dermatitis (McCall, Waisman, Elvehjem \& Jones, I946).

Man. The early appearance of angular stomatitis and cheilosis in the rat interested us in view of the possibility that deficiency of vitamin $\mathrm{B}_{6}$ produced these lesions in man (Smith \& Martin, 1940; Machella, 1942). Mueller \& Vilter (1950) produced acute deficiency of vitamin $\mathrm{B}_{6}$ in man by injecting deoxypyridoxin; they observed lesions mainly about the eyes, nose and lips. Wright, Samitz \& Brown (1943) made a 2-year trial of pyridoxin in various dermatoses and thought that some patients with seborrhoeic lesions were improved, but no controls were included; Pehl (I 940) had little success in juvenile seborrhoea. Jolliffe, Rosenblum \& Sawhill (x942) believed that therapy with pyridoxin was useful in most of their cases of adolescent acne vulgaris, but this condition is subject to spontaneous changes.

A careful study of the effect of pyridoxin in the dry type of seborrhoeic dermatitis has recently been published by Schreiner, Slinger, Hawkins \& Vilter (1952). They find that 'Natural seborrheic dermatitis does not clear with large amounts of pyridoxin administered parenterally or orally, but usually clears promptly over areas treated topically with pyridoxine ointment'.

\section{Haematopoietic tissue}

'Anaemia' occurs in rats deficient in vitamin $B_{6}$, and is rendered more severe by 
bleeding (Kornberg, Tabor \& Sebrell (1945) who measured the haemocrit only); the polycythaemic response to cobalt is abolished by deficiency (Hawkins, Lechow \& Evans, 1952). Carpenter \& Kodicek (1948-9) and Gubler, Cartwright \& Wintrobe (1949) found no significant reduction in haemoglobin concentration, whereas Agnew (1949) observed reductions in haemoglobin concentration and colour index; both Carpenter \& Kodicek and Agnew, however, observed a raised erythrocyte count, and the former workers found that the erythrocytes were microcytic. In our studies of weanling or adult rats pair-fed or fed ad lib. and receiving pteroylglutamic acid and deficient only in vitamin $\mathrm{B}_{6}$ (Ramalingaswami \& Sinclair, 1950b), polycythaemia occurred early; later there was a fall in haemoglobin concentration and haematocrit, with a severe microcytosis and normochromia. The plasma volume was normal, and the polycythaemia was the result of increased production of erythrocytes which were microcytic. There was apparently no defect in the synthesis of haemoglobin until relatively late in the deficiency. However, haemoglobin regeneration following repeated bleeding was severely impaired in deficiency of vitamin $\mathrm{B}_{6}$ and was restored by pyridoxin alone, cyanocobalamin producing no increase in the rate of regeneration (Ramalingaswmi \& Sinclair, 195I). Accompanying the microcytic normochromic ' anaemia ' in the rat there was haemosiderosis of the liver, spleen and bone marrow; in the liver the amounts of iron, nickel and lead appeared to be increased.

In the dog (Fouts, Helmer, Lepkovsky \& Jukes, 1938; Fouts, Helmer \& Lepovsky, 1940; Borson \& Mettier, I940; McKibbin, Schaefer, Frost \& Elvehjem, r942) and pig (Wintrobe, Follis, Miller, Stein, Alcayaga, Humphreys, Suksta \& Cartwright, I943) a greater disturbance of haematopoiesis occurs. The anaemia is microcytic and normochromic, and is accompanied by raised serum iron and marked haemosiderosis. Anaemia also occurs in chicks (Luckey, Briggs, Elvehjem \& Hart, r945), ducks (Hegsted \& Rao, I945) and monkeys (McCall et al. 1946). Hawkins subsisted on a purified diet deficient in vitamin $B_{6}$ for 56 days (Hawkins \& Barsky, 1948); it was considered that there was a possibility of changes in the neutrophil and lymphocyte counts, but this is scarcely supported by the figures presented. A mentally defective infant maintained on a diet deficient in vitamin $B_{6}$ for $1_{30}$ days (Snyderman, Carretero \& Holt, 1950) developed hypochromic anaemia which responded dramatically to pyridoxin.

\section{Nervous system}

Chick, El Sadr \& Worden (1940) described fits of an epileptiform nature in rats deprived of vitamin $\mathrm{B}_{6}$. Similar results were reported by Daniel, Kline \& Tolle (r942). In our rats we have not observed this in the absence of labyrinthitis, but we have regularly observed that the gait of the hind-limbs is 'spastic' (Ramalingaswami \& Sinclair, 195I): in severely affected animals the hind-limbs are rigid and kept in complete extension, the animal appearing to walk on the tips of the digits with the back arched and the pelvis carried high above the ground; ataxia is slight, there is no evidence of altered nociceptive or thermoceptive sensation, and there are no gross lesions in the cord. 
Convulsions and ataxia appear in pigs deficient in vitamin $\mathrm{B}_{6}$ (Wintrobe, Mushatt, Miller, Kolb, Stein \& Lisco, r942; Follis \& Wintrobe, 1945). There is demyelination of the sciatic and brachial nerves which is later found also in dorsal root fibres and the dorsal columns of the spinal cord.

In four undernourished patients, Spies, Bean \& Ashe (1939) reported a dramatic abolition of extreme nervousness, insomnia, irritability, abdominal pain, weakness and difficulty in walking after therapy with pyridoxin. Antopol \& Schotland (1940) thought this therapy was useful in pseudohypertrophic muscular dystrophy, and Rosenbaum, Portis \& Soskin (1942) in a case of neurasthenic muscular weakness. However, Ferrebee, Klinigman \& Frantz (I94I) were unsuccessful in muscular dystrophy or amyotrophic lateral sclerosis, and Eaton, Woltman \& Butt (194I) in the latter disease as well as progressive muscular dystrophy and progressive muscular atrophy. Spies, Hightower \& Hubbard (1940) thought pyridoxin was useful in treating patients with idiopathic epilepsy, amyotrophic lateral sclerosis, myasthenia gravis and Parkinsonism (both arteriosclerotic and postencephalitic); a case of arsenical neuritis was added to the list (Vilter, Aring \& Spies, 1940). Although some have also claimed benefits in some cases of Parkinsonism (Jolliffe, I940; Baker, I94I; Rudesill \& Weigand, I94I; Meller, 1942), others have been less fortunate or more critical (Zeligs, 194I; Barker, Stein, Miller \& Wintrobe, 194I ; Joughlin, Myersburg \& Wortis, r942). The claims of Stone (1944) and of Schwartzman, Dragutsky \& Rook (194I) for Sydenham's chorea can be ignored. No benefit was found in epilepsy (Fox \& Tullidge, 1946). There is no proved therapeutic use for pyridoxin in any neuro-muscular disorder.

\section{Miscellaneous}

Space does not permit of details of the failure of tumours to grow or of reduced immunity in deficiency of vitamin $B_{6}$, as well as various other events real or imaginary. Mention must, however, be made of the nausea and vomiting after radiation and during pregnancy. In the former, successful results of therapy with pyridoxin have been claimed by several authors (Maxfield, Mcllwain \& Robertson, 1943; Shorvon, 1946; Wells \& Popp, 1947). Nausea and vomiting of pregnancy have responded to therapy with pyridoxin according to several reports (Willis, Winn, Morris, Newsome \& Massey, 1942; Weinstein, Mitchell \& Sustendal, I943; Weinstein, Wohl, Mitchell \& Sustendal, I944; Silbernagel \& Burt, 1943), but Hesseltine (1946) found distilled water as effective. McGanity, McHenry, Van Wyck \& Watt (1949) reported biochemical evidence for the success of therapy with pyridoxin in hyperemesis gravidarum.

\section{Coenzyme functions of pyridoxal}

\section{Transamination}

This process, discovered by Braunstein \& Kritzmann (1937), involves the transfer of an amino-group from an $\alpha$-amino-acid to an $\alpha$-keto-acid, Highly purified 
preparations of glutamic-oxaloacetic and glutamic-pyruvic transaminases have been made. Snell $(1944,1945 a)$ found that autoclaving pyridoxal with an aminoacid produced pyridoxamine and the corresponding keto-acid, and that this reaction was reversible; he suggested therefore that vitamin $B_{6}$ might be concerned in biological transaminations. Schlenk \& Snell (1945) showed that tissues from rats deficient in vitamin $B_{6}$ had low transaminase activity which was increased by addition of pyridoxal and adenosine triphosphate. Further evidence was rapidly forthcoming that apotransaminase required pyridoxal phosphate (Lichstein, Gunsalus \& Umbreit, 1945; Green, Leloir \& Nocito, 1945; Schlenk \& Fisher, I947; Umbreit, O'Kane \& Gunsalus, 1946, 1948).

The initial hypothesis that the amino-group was transferred to pyridoxal with formation of pyridoxamine was tested by Gunsalus and Snell with colleagues and not supported (Gunsalus, 1950). Metzler \& Snell (1952a) found that this reversible non-enzymic reaction was catalysed by trace metals (aluminium, ferric, ferrous and cupric ions), and Baddiley (1952) has shown that pyridoxal readily forms coordination compounds with metal ions and amino-acids or ethylenediamine. His scheme is an attractive one.

The role of transamination in biological systems is not clear. It has been supposed to be involved in oxidative deamination of amino-acids (e.g. the conversion of tyrosine to $p$-hydroxyphenylpyruvic acid), in synthesis of aminoacids, in peptide-bond synthesis and in urea formation.

\section{Decarboxylation of amino-acids}

Ellinger's (1900) discovery of the formation of putrescine and cadaverine by decarboxylation of the corresponding amino-acids was followed by the isolation of various other amines from meat after putrefaction. Gale in 1940 (cf. Gale, 1946) studied the specific amino-acid decarboxylases of bacteria. Gunsalus and colleagues showed that pyridoxal phosphate was the coenzyme of tyrosine apodecarboxylase (Gunsalus, Bellamy \& Umbreit, I944). It was subsequently shown to be the coenzyme of the apodecarboxylase for six other amino-acids, and probably for histidine (Werle \& Koch, 1949). Werle showed that histamine was formed nonenzymically when histidine was heated at $60^{\circ}$ with pyridoxal phosphate. $\mathrm{He}$ (Werle, 1947-8) obtained no evidence, however, that mammalian holodecarboxylase of histidine contained pyridoxal phosphate although it was strongly inhibited by carbonyl-group reagents. Mammalian 'dopa' decarboxylase has pyridoxal phosphate as coenzyme (Green et al. 1945; Schales \& Schales, 1949); in rats deficient in vitamin $B_{6}$, the amount of this enzyme and of cysteic-acid decarboxylase in liver is decreased (Blaschko, Carter, O'Brien, \& Stanley, 1948).

The mechanism of decarboxylation, according to Werle, may be assumed to be the formation of a Schiff's base (I) which alters to a pyridoid structure (II) in which the carboxyl-group is made labile and lost (III): 
<smiles>[R]C(N)C(=O)OCCO</smiles>

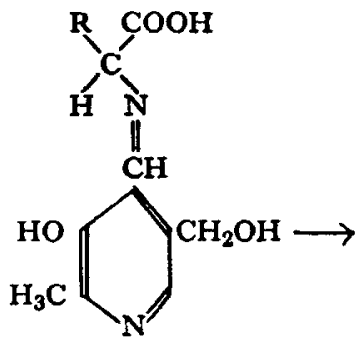

$\mathbf{I}$<smiles>[R]C(=O)C(=O)O</smiles>

II

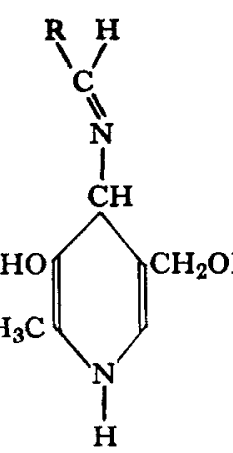

III

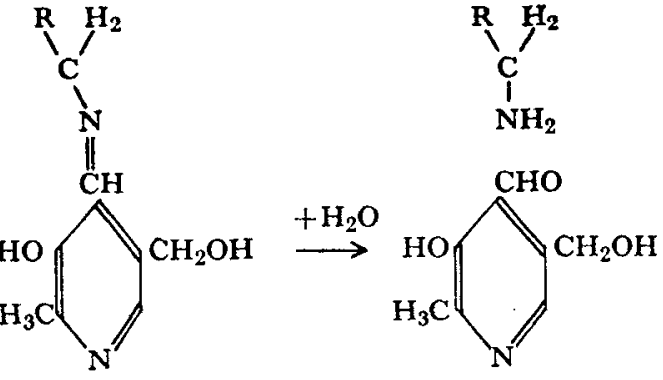

IV

\section{Racemization of amino-acids}

In the scheme just mentioned the formation of the hypothetical pyridoid structure (II) causes the asymmetry of the $a$-carbon of the amino-acid to be lost.

Snell \& Guirard (r943) showed that certain bacteria requiring vitamin $B_{6}$ for growth could use DL-alanine in place of the vitamin; D-alanine was subsequently shown to be the active factor (Snell, $1945^{b}$ ), and vitamin $B_{6}$ was needed for the synthesis of this from L-alanine if it was not supplied. Wood \& Gunsalus (I95I) showed that pyridoxal phosphate was the coenzyme of the racemase of L-alanine.

We have found no effect of $D$-alanine on rats deficient in vitamin $B_{6}$.

\section{Serine dehydrase and cysteine desulphydrase}

Serine and cysteine, unlike most other amino-acids, did not undergo transamination when heated with pyridoxal (Metzler \& Snell, r952a); instead ammonia and pyruvic acid were formed together with hydrogen sulphide in the case of cysteine (Meister, Sober \& Peterson, 1952). Pyridoxal phosphate is the coenzyme of both cysteine desulphydrase (Kallio, 195 I) and serine dehydrase (Metzler \& Snell, 1952b); metal ions are required (Metzler \& Snell, 1952b).

This may be regarded as a specialized case of the ordinary 'transamination' mechanism because, on Baddiley's scheme, transamination would not be expected to occur with these two amino-acids. The stages may be pictured as follows: 
<smiles>C=C(C)N(C)[C@H](C)C(=O)O</smiles><smiles>CC(=O)C(=O)CC(C)C(=O)O</smiles>

Pyridoxal phosphate has been shown to be a coenzyme in the synthesis of cysteine from cystathionine in rats (Binkley, Christensen \& Jensen, 1952).

\section{Tryptophan synthesis and degradation}

Rats deficient in vitamin $B_{6}$ excrete large amounts of xanthurenic acid in the urine which are increased by adding more casein or tryptophan to the diet. In neurospora, pyridoxal phosphate was shown to be the coenzyme for the conversion of indole and serine into tryptophan (Umbreit, Wood \& Gunsalus, 1946):<smiles>c1ccc2[nH]ccc2c1</smiles><smiles>NC(CO)C(=O)O</smiles><smiles>CCO</smiles><smiles>NC(Cc1c[nH]c2ccccc12)C(=O)O</smiles>

Indole not so used may form xanthurenic acid and kynurenine.

Pyridoxal phosphate was also shown to be the coenzyme of tryptophanase which breaks tryptophan into indole, pyruvic acid and ammonia in Bacterium coli (Wood, Gunsalus \& Umbreit, 1947); and for the conversion of tryptophan into nicotinic acid in rats (Schweigert \& Pearson, 1947).

\section{Histaminase (diamine oxidase)}

This enzyme was discovered by Eustis (I9I5), rediscovered by Best (1929) and named by Best \& McHenry (1930). Zeller, Stern \& Wenk (1940) considered it was a flavoprotein with a carbonyl-group in the prosthetic group. Werle \& Pechmann 
(1949) thought that pyridoxal phosphate might be part of plant diamine oxidase, and found that pyridoxal hydrochloride slightly increased the activity of the dialysed enzyme from clover seedlings.

Our own preliminary results (Sinclair, 1952a) suggested that pyridoxal phosphate might be a coenzyme of histaminase of animal tissues, and it seemed possible that the lesions of the skin and mucocutaneous junctions and the priapism in deficiency of vitamin $B_{6}$ might be secondary to a vascular change produced by abnormal concentrations of histamine. However, our estimations of histamine in tissues of rats deficient in vitamin $B_{6}$ have not shown any significant increase from levels in control rats; nor have we achieved any improvement in the signs of deficiency by the oral administration of mepyramine, which is a more specific antihistamine than is pyribenzamine which we used earlier. We have therefore discarded this hypothesis.

Since semicarbazide is a powerful inhibitor of enzymes containing a carbonylgroup as a prosthetic group as in pyridoxal, and since it also powerfully inhibits histaminase, we administered it (Io mg weekly) to rats on a diet deficient in fat and vitamin $B_{6}$. It caused a rapid loss of weight and greatly accelerated the onset of the typical signs of deficiency of vitamin $B_{6}$. There was a slight indication that these signs were less in animals receiving mepyramine, but the daily urinary excretion of histamine was not affected by deficiency of vitamin $B_{6}$ or addition of semicarbazide. Administration of pyridoxin hydrochloride $(2.5 \mathrm{mg}$ daily) while continuing the semicarbazide caused a rapid gain in weight and disappearance of the signs. In contrast, Parks, Kidder \& Dewey (1952) found only sporadic reversal of acute toxicity of semicarbazide in mice by pyridoxamine, and found no increased toxicity of thiosemicarbazide in mice deficient in pyridoxin. Thiosemicarbazones are used in the treatment of pulmonary tuberculosis, and so is isonicotinic acid hydrazide which also competes with pyridoxal (Yoneda, Kato \& Okajima, 1952). Another compound with similar therapeutic properties, $p$-aminosalicylic acid, is similar to pyridoxal when reduced to its aldehyde, and streptidine (which is linked through a glucoside linkage to a disaccharide to give streptomycin) has some points of similarity. All these compounds except streptomycin combine with pyridoxal, though this is not necessarily the reason for their toxicity to tubercle bacilli.

\section{Discussion and correlation}

Six connexions between protein and vitamin $B_{6}$ were early noticed. First, deficient rats (Lepkovsky, Roboz \& Haagen-Smit, r943) or mice (Miller \& Baumann, 1945) excrete large amounts of xanthurenic acid in the urine which are increased by adding more casein or tryptophan to the diet; excretion of kynurenic acid is decreased. Secondly, deficiency of vitamin $\mathrm{B}_{6}$ decreases the amount of protein and of water in the body of growing rats, more so in males than in females, but does not affect the amount of fat gained (Voris \& Moore, I943); Carter \& Phizackerley (195I) obtained results consistent with the view that the rat deficient in vitamin $\mathrm{B}_{6}$ has impaired ability to synthesize fat from carbohydrate, and they found decreased oxidation of butyrate and octanoate in liver slices from deficient rats. Thirdly, 
the signs of deficiency are more severe when a high-casein diet is fed to rats (Cerecedo \& Foy, 1944) or mice (Schweigert, Sauberlich, Elvehjem \& Baumann, 1946). Fourthly, in deficient rats on a high-protein diet the fasting levels of blood urea and non-protein nitrogen are increased (Hawkins, MacFarland \& McHenry, 1946). Fifthly, L-tyrosine is less toxic to rats deficient in vitamin $B_{6}$ (Martin, 1946). Sixthly the toxicity of DL-serine to rats appears to be decreased by pyridoxin (Sydenstricker, Singal, Briggs, De Vaughn \& Isbell, 1942).

All the proved functions of pyridoxal as a coenzyme are associated with groups attached to the $\alpha$-carbon of an $\alpha$-amino-acid. It is not therefore surprising that various derangements of protein metabolism occur in deficiency of vitamin $B_{6}$. Such derangements would be expected to cause severe interference with the growth of the body, and this is an early sign of deficiency. Those tissues of the body that are rapidly growing might be expected to suffer most, and this appears to be so: tumours fail to grow or grow slowly; derangements of the skin and of haematopoiesis occur.

The lesions in the skin would be expected to occur in those areas where there is most trauma and therefore where epithelial regeneration is most required. The paws, parts of the face and particularly mucocutaneous junctions are the obvious sites and are indeed affected earliest and most severely, although histological lesions are later demonstrable also in less vulnerable areas such as the skin of the abdomen. I have recently discussed elswhere (Sinclair, $195^{2} b$ ) the resemblances and differences between the lesions in deficiencies of vitamin $B_{6}$ and of essential fatty acids: it is suggested that in the latter deficiency the characteristically sudden and complete cessation of growth is caused by an insufficiency of the necessary unsaturated fatty acid or acids for the formation of the phospholipins of new cell membranes or the cytoskeleton; the acanthosis may occur for the same reason, and a striking feature is the increased permeability of the skin to water, which is not found in deficiency of vitamin $\mathrm{B}_{6}$; hence probably the marked changes in the ears in deficiency of essential fatty acids which are not found in deficiency of vitamin $B_{6}$. In either deficiency the skin responds dramatically to slight injury such as mild irradiation of the skin from a mercury-vapour lamp; although vitamin $\mathbf{B}_{\mathbf{6}}$ is easily destroyed by ultraviolet light, this is not the cause of the injury which is unaffected by local therapy with the vitamin. It is reasonable to suppose that the vascular changes in deficiency of vitamin $B_{6}$ are secondary to those in the epithelial cells. It might be supposed that changes would be found in the epithelium of the cornea and conjunctiva, but these and corneal vascularization are strikingly absent; but the epithelial cells of the eye are well protected and not subjected to trauma as are those of mucocutaneous junctions.

'Anaemia' is found in deficiency of pyridoxin and of essential fatty acids. In the former, as already mentioned, it is microcytic and usually hypochromic with raised serum iron and haemosiderosis; in the latter it is much milder though similar in that there is microcytosis and polycythaemia, but the concentration of haemoglobin is normal or raised and there is also mild leucopenia (Ramalingaswami \& Sinclair, 195I). The microcytosis and polycythaemia of deficiency of pyridoxin 
with increased serum iron are probably caused by the deficient synthesis of protoporphyrin found by Cartwright \& Wintrobe (1948); the work of Shemin (1948) and of Neuberger (1952) with their colleagues has shown that glycine is a specific precursor of all four pyrrolic rings in porphyrin, and it is obvious that pyridoxal may again be concerned with the metabolism of an amino-acid in this synthesis though there is as yet no evidence. The microcytosis and polycythaemia of deficiency of essential fatty acids with normal formation of haemoglobin and normal levels of iron in the body may be caused by the deficient formation of the proteinlipid complex of the stroma of the erythrocyte.

It is idle to speculate about the origin of the lesions in the nervous system; the presence of serine in certain kephalins raises a possibility. Nor is it profitable to speculate about the apparent benefits of pyridoxin in radiation sickness (though it may be noted in passing that radiation increases the hydrogen peroxide in tissues and this quite easily destroys the vitamin) or in hyperemesis gravidarum (in which, however, McGanity et al. (1949) have demonstrated a biochemical lesion of deficiency of vitamin $\mathrm{B}_{6}$ ). And no mention will be made of the growth-promoting properties of vitamin $B_{6}$ in micro-organisms since these have been excellently correlated with the chemical and enzymic properties by Snell (1952).

The very rapid recent progress in elucidating the coenzymic functions of pyridoxal has greatly aided the interpretation of the lesions that occur in deficiency in lower animals and also in man, but much more work remains to be done.

\section{SUMMARY}

I. The biological effects in animals of deficiency of vitamin $B_{6}$ are seen mainly in the skin, haematopoietic tissue and nervous system.

2. The lesion in the skin consists essentially of atrophy of the transitional layers with surface hyperkeratosis; it occurs earliest and is most marked in the areas subjected to trauma, such as the paws and parts of the face and mucocutaneous junctions. The same appears to be true of man: cheilosis and angular stomatitis occur, and some cases of dry seborrhoeic dermatitis respond to therapy with pyridoxin.

3. The change in the blood is a microcytosis accompanied by polycythaemia and slight hypochromia and later a fall in haemoglobin concentration; serum iron is increased and there is haemosiderosis.

4. Epileptiform convulsions occur in lower animals and demyelination of peripheral nerves and of the dorsal columns of the cord may be found. There is no proved therapeutic use for pyridoxin in any human neuro-muscular disorder. Such therapy appears to be beneficial in the nausea and vomiting after radiation and during pregnancy.

5. Pyridoxal phosphate is a coenzyme in transamination, and for the apoenzymes serine dehydrase and cysteine desulphydrase which probably combine with substrate, metal ions and coenzyme in a similar way to apotransaminases. 
6. Pyridoxal phosphate is also a coenzyme for the decarboxylation of certain a-amino-acids, and for the racemization of L-alanine which may occur by a similar initial process.

7. Pyridoxal phosphate is also concerned with tryptophan synthesis and cleavage. The weight of evidence is against its being part of histaminase (diamine oxidase). Semicarbazide, which combines with pyridoxal, produces lesions in rats identical with those of deficiency of vitamin $\mathbf{B}_{6}$ that are reversed by pyridoxin.

8. Those tissues of the body that are rapidly growing appear to suffer most in deficiency of vitamin $B_{6}$, probably because all the functions of pyridoxal as a coenzyme so far proved are associated with groups attached to the $\alpha$-carbon atom of an $\alpha$-amino-acid and therefore intimately connected with protein metobalism. The lesions of the skin occur in areas where epithelial regeneration is most required; they differ from the lesions in deficiency of essential fatty acids. The changes in haematopoietic tissue are probably caused by deficient synthesis of protoporphyrin.

The work of the Laboratory of Human Nutrition described above was done with Dr. V. Ramalingswami, assisted by Miss Joyce Buxton and Miss Agnes Mayer, to all of whom I express my gratitude.

\section{REFERENCES}

Agnew, L. R. C. (1949). Brit. F. Nutr. 3, 2 I7.

Antopol, W. \& Schotland, C. E. (1940). F. Amer. med. Ass. 114, 1058.

Antopol, W. \& Unna, K. (1942). Arch. Path. 33, 24I.

Baddiley, J. (1952). Nature, Lond., I7o, 7 II.

Baker, A. B. (1941). F. Amer. med. Ass. rr6, 2484.

Barker, W. H., Stein, J., Miller, M. H. \& Wintrobe, M. M. (194I). Fohns Hopk. Hosp. Bull. $69,266$.

Best, C. H. (1929). F. Physiol. 67, 256.

Best, C. H. \& McHenry, E. W. (I930). F. Physiol. 70, 349.

Binkley, F., Christensen, G. M. \& Jensen, W. N. (1952). F. biol. Chem. 194, ro9.

Blaschko, H., Carter, C. W., O'Brien, J. R. P. \& Stanley, G. H. S. (1948). F. Physiol. ro7, I8P.

Borson, H. J. \& Mettier, S. R. (1940). Proc. Soc. exp. Biol., N.Y., 43, 429.

Braunstein, A. E. \& Kritzmann, M. G. (1937). Enzymologia, 2, 129.

Carpenter, K. J. \& Kodicek, E. (1948-9). Brit. F. Nutr. 2, ix.

Carter, C. W. \& Phizackerley, P.J.R. (I951). Biochem. F. 49, 227.

Cartwright, G. E. \& Wintrobe, M. M. (1948). F. biol. Chem. 172, 557.

Cerecedo, L. R. \& Foy, J. R. (1944). Arch. Biochem. 5, 207.

Chick, H., El Sadr, M. M. \& Worden, A. N. (1940). Biochem. F. 34, 595 .

Daniel, E. P., Kline, O. L. \& Tolle, C. D. (1942). 7. Nutr. 23, 205.

Eaton, L. M., Woltman, H. W. \& Butt, H. R. (r94I). Proc. Mayo Clin. 16, 523.

Ellinger, A. (1900). Hoppe-Seyl. Z. 29, 334.

Eustis, A. C. (1915). Biochem. Bull. 4, 97.

Ferrebee, J. W., Klinigman, W. O. \& Frantz, A. M. (194I). 7. Amer. med. Ass. 116, I895.

Follis, R. H. Jr. \& Wintrobe, M. M. (1945). F. exp. Med. 8r, 539.

Fouts, P. J., Helmer, O. M. \& Lepkovsky, S. (1940). Amer. F. med. Sci. 199, 163.

Fouts, P. J., Helmer, O. M., Lepkovsky, S. \& Jukes, T. H. (1938). F. Nutr. I6, I97

Fox, J. T. \& Tullidge, G. M. (1946). Lancet, 25I, 345 .

Gale, E. F. (1946). Advanc. Enzymol. 6, г.

Goldberger, J. \& Lillie, R. D. (1926). Publ. Hlth Rep., Wash., 41, 1025.

Green, D. E., Leloir, L. F. \& Nocito, V. (1945). F. biol. Chem, 161, 559.

Gubler, C. J., Cartwright, G. E. \& Wintrobe, M. M. (1949). F. biol. Chem. 178, 989.

Gunsalus, I. C. (1950). Fed. Proc. 9, 556.

Gunsalus, I. C., Bellamy, W. D. \& Umbreit, W. W. (r944). F. biol. Chem. r55, 685 .

György, P. (1934). Nature, Lond., I33, 498.

György, P. (1938). F. Amer. chem. Soc. 6o, 983 . 
György, P. \& Eckhardt, R. E. (1939). Nature, Lond., 144, 5 I 2.

Harris, S. A. \& Folkers, K. (1939a). Science, 89, 347.

Harris, S. A. \& Folkers, K. (1939b). F. Amer, chem. Soc. 61, 1245.

Hawkins, W. W. \& Barsky, J. (1948). Science, 108, 284.

Hawkins, W. W., Lechow, B. \& Evans, N. K. (1952). Amer. F. Physiol. 170, 55.

Hawkins, W. W., MacFarland, M. L. \& McHenry, E. W. (1946). F. biol. Chem. r66, 223.

Hegsted, D. M. \& Rao, M. N. (1945). F. Nutr. 30, 367.

Hesseltine, H. C. (1 946). Amer. F. Obstet. Gynec. 51, 82.

Itiba, A. \& Miti, K. (1938). Sci. Pap. Inst. phys. chem. Res. Tokyo, 34, 623.

Jolliffe, N. (1940). Trans. Amer. neurol. Ass. 66, 54.

Jolliffe, N., Rosenblum, L. A. \& Sawhill, J. (1942). F. invest. Derm. 5, 143.

Kallio, R. E. (195I). Bact. Proc. p. $13 \mathrm{I}$

Keresztesy, J. C. \& Stevens, J. R. (1938). Proc. Soc. exp. Biol., N.Y., 38, 64,

Kornberg, A., Tabor, H. \& Sebrell, W. A. (1945). Amer. F. Physiol. 143, 434.

Kuhn, R. \& Wendt, G. (1938a). Ber. 71, 780 .

Kuhn, R. \& Wendt, G. (1938b). Ber. 71, xi18.

Kuhn, R., Westphal, K., Wendt, G. \& Westphal, O. (1939). Naturwissenschaften, 27, 469.

Lepkousky, S. (1938a). Science, 87, 169 .

Lepkovsky, S. (1938b). F. biol. Chem. 124, 125.

Lepkovsky, S., Roboz, E. \& Haagen-Smit, A. J. (1943). F. biol. Chem. 149, 195.

Lichstein, H. C., Gunsalus, I. C. \& Umbreit, W. W. (1945). F. biol. Chem. I6r, 3 I I.

Loughin, W. C., Myersburg, H. A., \& Wortis, H. (1942). Ann. intern. Med. 17, 423.

Luckey, T. D., Briggs, G. M. Jr., Elvehjem, C. A. \& Hart, E. B. (1945). Proc. Soc. exp. Biol, N.Y., $58,340$.

McCall, K. B., Waisman, H. A., Elvehjem, C. A. \& Jones, E. S. (1946). 7. Nutr. 31, 685.

McGanity, W. J., McHenry, E. W., Van Wyck, H. B. \& Watt, G. L. (1949). F. biol. Chem. I78, 511 .

Machella, T. E. (1942). Amer. F. med. Sci. 203, I 14.

McKibbin, J. M., Schaefer, A. E., Frost, D. V. \& Elvehjem, C. A. (1942). F. biol. Chem. 142, 77.

Martin, G. J. (1946). F. biol. Chem. 166, $3^{89}$.

Maxfield, J. R., McIlwain, A. J. \& Robertson, J. E. (1943). Radiol. 41, 383.

Meister, A., Sober, H. A. \& Peterson, E. (I952). F. Amer. chem. Soc. 74, 2385.

Meller, C. L. (1942). Minn. Med. 25, 22.

Metzler, D. E. \& Snell, E. E. (1952a). F. Amer. chem. Soc. 74, 979.

Metzler, D. E. \& Snell, E. E. (1952b). F. biol. Chem. 198, 353.

Miller, E. C. \& Baumann, C. A. (1945). F. biol. Chem. r57, 55 I.

Morii, S. \& Makino, K. (1939). Enzymologia, 7, 385.

Mueller, J. F. \& Vilter, R. W. (1950). J. clin. Invest. 29, 193.

Neuberger, A. (1952). Congr. int. Biochim. II. Paris. Symposium sur la Biochimie de l'Hematopoièse, p. 107.

Parks, R. E. Jr., Kidder, G. W. \& Dewey, V. C. (1952). Proc. Soc. exp. Biol., N.Y., 79, 287.

Pehl, W. (1940). Z. Kinderheilk. 6r, 613.

Ramalingaswami, V. \& Sinclair, H. M. (1950a). Brit. F. Nutr. 4, xiii.

Ramalingaswami, V. \& Sinclair, H. M. (1950b). Proc. int. Soc. Hematol, Paper no. 167.

Ramalingaswami, V. \& Sinclair, H. M. (I95I). Unpublished observations.

Ramalingaswami, V. \& Sinclair, H. M. (1953). F. invest. Derm. (In the Press.)

Rosenbaum, E. E., Portis, S. \& Soskin, S. (1942). F. Lab. clin. Med. 27, 763.

Routh, J. I. \& Houchin, O. B. (1942). Fed. Proc. I, 191.

Rudesill, C. L. \& Weigand, C. G. (I94I). F. Indian med. Ass. 34, 355.

Schales, O. \& Schales, S. S. (1949). Arch. Biochem. 24, 83.

Schlenk, F. \& Fisher, A. (1947). Arch. Biochem. 12, 69.

Schlenk, F. \& Snell, E. E. (1945). 7. biol. Chem. 157, 425.

Schreiner, A. W., Slinger, W., Hawkins, V. R. \& Vilter, R. W. (1952). F. Lab. clin. Med. 40, I2I.

Schwartzman, J., Dragutsky, D. \& Rook, C. (1941). F. Pediat. r9, 201.

Schweigert, B. S. \& Pearson, P. B. (1947). $¥$. biol. Chem. 168, 555.

Schweigert, B. S., Sauberlich, H. E., Elvehjem, C. A. \& Baumann, C. A. (1946). F. biol. Chem. 165, 187.

Shemin, D. (1948). Cold Spr. Harb. Symp. quant. Biol. 13, 185.

Shorvon, L. M. (1946). Brit. F. Radiol. 19, 369.

Silbernagel, W. M. \& Burt, O. P. (1943). Ohio St. med. F. 39, II I3.

Sinclair, H. M. (1952a). Biochem. F. 51, x.

Sinclair, H. M. (1952b). Symp. biochem. Soc. no. 9, p. 80.

Smith, S. G. \& Martin, D. W. (1940). Proc. Soc. exp. Biol., N.Y., 43, 660.

Snell, E. E. (1944). F. biol. Chem. 154, 313 . 
Snell, E. E. (1945a). F. Amer. chem. Soc. 67, 194.

Snell, E. E. (1945b). $\mathscr{~}$. biol. Chem. 158, 497.

Snell, E. E. (r952). Congr. int. Biochim. II. Paris. Symposium sur le Métabolisme Microbien, p. 47.

Snell, E. E. \& Guirard, B. M. (1943). Proc. nat. Acad. Sci., Wash., 29, 66.

Snyderman, E., Carretero, R. \& Holt, L. E. Jr. (1950). Fed. Proc. 9, 371.

Spies, T. D., Bean, W. B. \& Ashe, W. F. (1939). F. Amer. med. Ass. r12, 2414.

Spies, T. D., Hightower, D. P. \& Hubbard, L. H. (1940). F. Amer. med. Ass. 115, 292.

Stone, S. (1944). F. nerv. ment. Dis. 100, 185.

Sullivan, M. \& Nicholls, J. (1940). F. invest. Derm. 3, 317.

Sydenstricker, V. P., Singal, S. A., Briggs, A. P., De Vaughn, N. M. \& Isbell, H. (1942). F. Amer. med. Ass, II8, I 199.

Umbreit, W. W., O'Kane, D. J. \& Gunsalus, I. C. (1946). F. Bact. 5x, 576.

Umbreit, W. W., O'Kane, O. S. \& Gunsalus, I. C. (1948). F. biol. Chem. 176, 629.

Umbreit, W. W., Wood, W. A. \& Gunsalus, I. C. (1946). F. biol. Chem. 165, 73 I.

Vilter, R. W., Aring, C. D. \& Spies, T. D. (1940). F. Amer, med. Ass. 115, 839.

Voris, Le R. \& Moore, H. P. (I 943). F. Nutr. 25, 7.

Weinstein, B. B., Mitchell, G. J. \& Sustendal, G. F. (1943). Amer. F. Obstet. Gynec. 46, 283.

Weinstein, B. B., Wohl, Z., Mitchell, G. J. \& Sustendal, J. E. (1944). Amer. F. Obstet. Gynec. 47, 389.

Wells, J. J. \& Popp, W. C. (r947). Proc. Mayo Clin. 22, 482.

Werle, E. (1947-8). Z. Vitam.- Horm.- u. Fermentforsch. r, 504.

Werle, E. \& Koch, W. (1949). Biochem. Z. 319, 305.

Werle, E. \& Pechmann, E. V. (1949). Liebigs Amn. 562, 44.

Willis, R. S., Winn, W. W., Morris, A. T., Newsome, A. A. \& Massey, W. S. (1942). Amer. F. Obstet. Gynec. 44, 265 .

Wintrobe, M. M., Follis, R. H. Jr., Miller, M. H., Stein, H. J., Alcayaga, R., Humphreys, S., Suksta, A. A. \& Cartwright, G. E. (1943). Fohns Hopk. Hosp. Bull. 72, 1.

Wintrobe, M. M., Mushatt, C., Miller, J. L. Jr., Kolb, L. C., Stein, H. J. \& Lisco, H. (1942). F. clin. Invest. 2I, $7 \mathrm{I}$.

Wood, W. A. \& Gunsalus, I. C. (195I). Y. biol. Chem. rgo, 403.

Wood, W. A., Gunsalus, I. C. \& Umbreit, W. W. (1947). F. biol. Chem. 170, 313.

Wright, C. S., Samitz, M. H. \& Brown, H. (1943). Arch. Derm. Syph. 47, 651 .

Yoneda, M., Kato, N. \& Okajima, M. (1952). Nature, Lond., 170, 803.

Zeligs, M. A. (1941). F. Amer. med. Ass. I16, 2148.

Zeller, E. A., Stern, R. \& Wenk, N. (1940). Helv. chim. Acta, 23, 3.

\title{
Present Knowledge of the Metabolic Role of Vitamin $B_{12}$ and Related Compounds, with Particular Reference to the Role of Cobalt in Ruminant Metabolism
}

\author{
By J. W. G. PorTer, National Institute for Research in Dairying, \\ University of Reading
}

The chemistry of vitamin $\mathrm{B}_{12}$, its determination by microbiological assay, its relation to anaemia and its nutritional significance as part of the animal protein factor were discussed at a Nutrition Society symposium last January (Smith, 1952; Ford, 1952; Ungley, 1952; Girdwood, 1952; Cuthbertson, 1952; Coates, 1952). This paper presents some of the evidence now available concerning the ways in which vitamin $B_{12}$ functions in metabolic processes in higher animals and in microorganisms. The topics discussed have been restricted to those in which vitamin $\mathrm{B}_{12}$ has a well authenticated role. The later sections include a discussion of the occurrence of cobalt-containing compounds related to vitamin $B_{12}$ but not members of the cobalamin series, and their possible function in the growth and metabolism of the microbial flora of the gut. 